\title{
THE FIRST LATE CRETACEOUS (MAASTRICHTIAN) DINOSAUR FOOTPRINTS FROM TRANSYLVANIA (ROMANIA)
}

\author{
MATEI VREMIR ${ }^{1}$, VLAD A. CODREA ${ }^{1}$
}

\begin{abstract}
An Uppermost Cretaceous (Maastrichtian) site exposing dinosaur footprints is reported from the Sebes area (Transylvanian Depression). This is the first dinoturbated layer discovered in our country, containing also numerous bones belonging to various dinosaurs.

The track-site is located near Lancră $m$ village and provides only two quite well preserved footprints (one track). The medium sized ( $F L=23,3 \mathrm{~cm}$; $F W=17,8 \mathrm{~cm}$; pace $=103 \mathrm{~cm} ; \mathrm{ST}=200 \mathrm{~cm}$ ) plantigrad-tridactyle footprints belong to Ornithopedoidei, according to their morphology. An assignment to the Iguanodontichnus CASAMIQUELA \& FASOLA, 1968 group seems to be appropriate (tentatively, associated to the "Rhabdodon" iguanodontian dinosaur).

The importance of this discovery lies in the stratigraphical significance, confirming the Uppermost Cretaceous age of these dinosaur-bearing continental deposits exposed between Sebes and Alba-lulia (as well as the autochthon/ paraautochon status of some vertebrate assemblages identified there), which previously were considered Oligocene or even Miocene. Additional data regarding size, speed and locomotion of the Transylvanian Iguanodontian "Rhabdodon" dinosaurs are added.
\end{abstract}

KEYWORDS: Dinosaur ichnology; footprints (Ornithopedoidel); Late Cretaceous; Transylvanian Depression; Romania.

\section{INTRODUCTION}

Upper Cretaceous dinosaur footprints where rarely recorded worldwide. Only few sites are registered from the Tremp Fm, Pyrenees in Spain (LopezMartinez et al., 1999), Istria Peninsula in Croatia (Dalla Vecchia et al., 2001), Catalonia (NE Spain), Agadir (Morocco), Yacorite Fm (Argentina), St. Mary River Fm and Edmonton Fm, Alberta, in Canada (Haubold, 1984). Famous sites are also well known from the Mesa Verde Beds of Colorado and Utah, the Laramie Beds of Colorado, Hondo Creek, Texas (USA), Toro Toro (Bolivia), Winton Beds in Australia (Lockley, 1991) and Anhui province (China; Yu et al., 1999).

In our country, Tertiary tetrapod footprints are quite frequently identified in various sites, especially in the Oligo-Miocene deposits of the Eastern Carpathians. The Mesozoic such discoveries are extremely rare, either in Romania or in the surrounding countries, where dinosaur footprints are scarce. The most interesting finds are recorded from the Early Jurassic (Liassic) of Hungary (Kordos, 1983; Gierlinski, 1996).

\footnotetext{
${ }^{1}$ Babeş-Bolyai University, Faculty of Biology and Geology, Department of Geology-Paleontology, 1 Kogălniceanu Str., 3400 Cluj-Napoca. Correspondence and reprints: vcodrea@bioge.ubbcluj.ro
} 
The first record of a Mesozoic tetrapod footprint in Romania originates from the Early Cretaceous (Neocomian) of Lă puș (Maramureș District; Koch, 1900). It seems to be a "footprint" belonging to a "large cheloniid" (?Testudipedida VIALOV), but the reexamination of this ichnofossil is unaivailable now (unknown collection).

After near a century, a second contribution on this topic belongs to Popa (1999), who descibes a pair of poorly preserved footprints (manus and pes) from the Lower Liassic Steierdorf Fm (Hettangian) of Anina. In the author's oppinion, the footprints (ichnogenus Batrachopus HITCHCOCK) are assigned to an archaic crocodilian.

During the recent field-missions carried on in the Uppermost Cretaceous dinosaur-bearing continental deposits ("lower red beds" or LRB Fm) from Sebes region (Transylvanian Depression), a new site was identified, exhibiting dinosaur footprints. The site is located NW from Lancră $m$ village (LC), on the Sebes Valley. It represents the first ichnological record related to the dinosaurs from Transylvania.

\section{GEOLOGICAL SETTING}

The development of the Transylvanian-Pannonian landmass (an emerged area, covering more than $45000 \mathrm{sq}$. $\mathrm{km}$, part of an island arch belonging to the Alpine chain) is related to the Laramian tectogenesis. The movements in the North

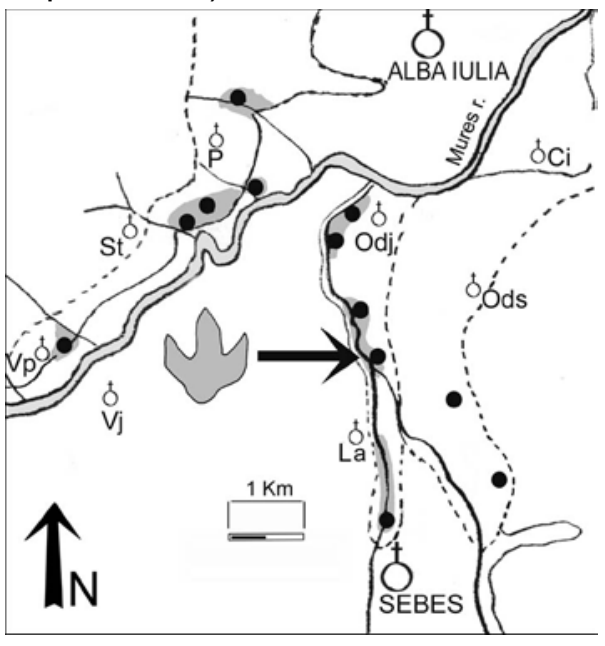

Fig. 1 Site location on the map Tethyan realm at the end of Cretaceous (about $72 \mathrm{MY}$ ago), controlled its evolution.

Uppermost Cretaceous (Maastrichtian) continental deposits bearing dinosaur remains, are exposed in the Hat eg Basin (also known as "Hat eg island"), as well as in the western and northern parts of the Transylvanian Depression, in Alba lulia and Jibou regions. Continental red beds, lying on the folded nappes of the Transylvanids (Să ndulescu, 1984), represent the oldest post-Laramian formations on the western border of the Transylvanian Depression.

The main outcropping area is outlined by the localities Vurpă $r$ - Ighiu - Oarda de Jos - Sebes, all in Alba district (Fig. 1). The continental "red beds" exposed there belongs to several distinct lithostratigraphic units, whose spatial and temporal relationship is not precisely clarified until now. From lithostratigraphic/ faciesal perspective, the Upper Campanian - Lower Maastrichtian deltaic sediments (the top of the Bozes Fm) are overlapped by fluvio-lacustrine deposits, represented by large aluvial fans, floodplain sediments with channel fills, overbank as well as lacustrine deposits, belonging to a braided river-type system (Codrea et al., 
$2001 \mathrm{a}, \mathrm{b}, 2002)$.

OUTCROP

Lancră $\boldsymbol{m}$-Sebeș Valley (LC). It was discovered in October 2000, in the Sebes Valley riverbed, $1.5 \mathrm{~km}$ NNE from Lancră $\mathrm{m}$, more precisely a half of $\mathrm{km}$ downstream from the confluence with the Secas stream, on the left bank of a wide

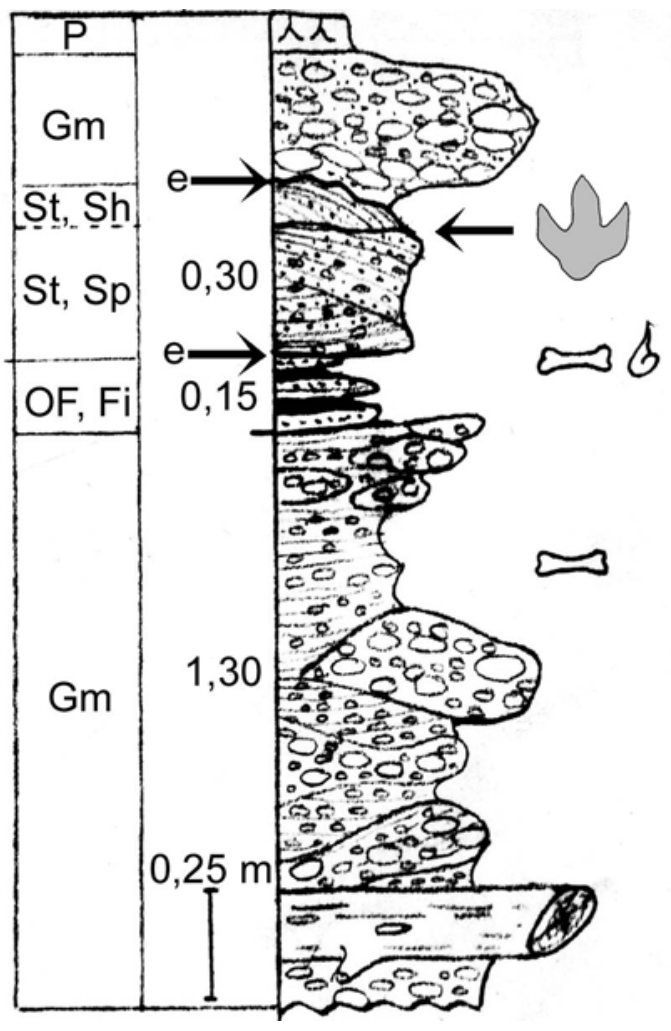

Fig.2 Stratigraphical log on the left bank of Sebes River meander. The studied bedding plane exhibits two footprints in the same track, belonging to a medium sized tridactyl-plantigrad morphotype. The whole sequence is exposed on the right-bank on a thickness of approximately $28 \mathrm{~m}$. The stratigraphical log on the left riverbank is the following (Fig. 2):

$1.3 \mathrm{~m}=(\mathrm{Gm})$ coarse gravel with high rounded elements, dinosaur bones and tree trunks (channel lag deposit);

$0.15 \mathrm{~m}=(\mathrm{OF}, \mathrm{Fl})$ laminated siltoarenites, with interbedded thin coal films containing plant remnants, freshwater snails and dinosaur bones (overflow-marshy deposits);

$0.30 \mathrm{~m}=(\mathrm{St}, \mathrm{Sp})$ trough crossbedded coarse arenites (lateral accretion). Approximately $10 \mathrm{~cm}$ below the upper limit (major erosion discontinuity on left bank), the bedding plane exhibits the dinoturbated surface;

$0.65 \mathrm{~m}=(\mathrm{Gm}, \mathrm{P})$ coarse gravel, subsequently covered by soil (recent terrace - left bank).

\section{METHOD AND MATERIALS}

The fieldwork was focussed on mapping the dinoturbated surfaces. The footprints were outlined with chalk and subsequently copies were made on transparent polyethylene sheets, using waterproof felt pen. Besides the exact reproduction of the structures, photos were made when the light was the most convenient. The best-preserved footprint was cast with plaster. Measurements were taken in situ, as well as on the basis of the transparent copies like the drawings were made. Because in Transylvania we have to deal with the so-called 
"dwarf-dinosaurs", we chose to follow the dimensional-classification used by Dalla Vecchia et al. (2001): small = up to $15 \mathrm{~cm}$; medium $=15-25 \mathrm{~cm}$; large = over $25 \mathrm{~cm}$.

Only two footprints (hypichnia) are preserved as natural molds (negative/ concave epirelief), belonging to the same track, marked LCT 1-1 and LCT 1-2, which is also the best preserved one as true impression. Terms and methods were used according to Leonardi (1987), Thulborn (1990) and Lockley (1991).

\section{DESCRIPTION}

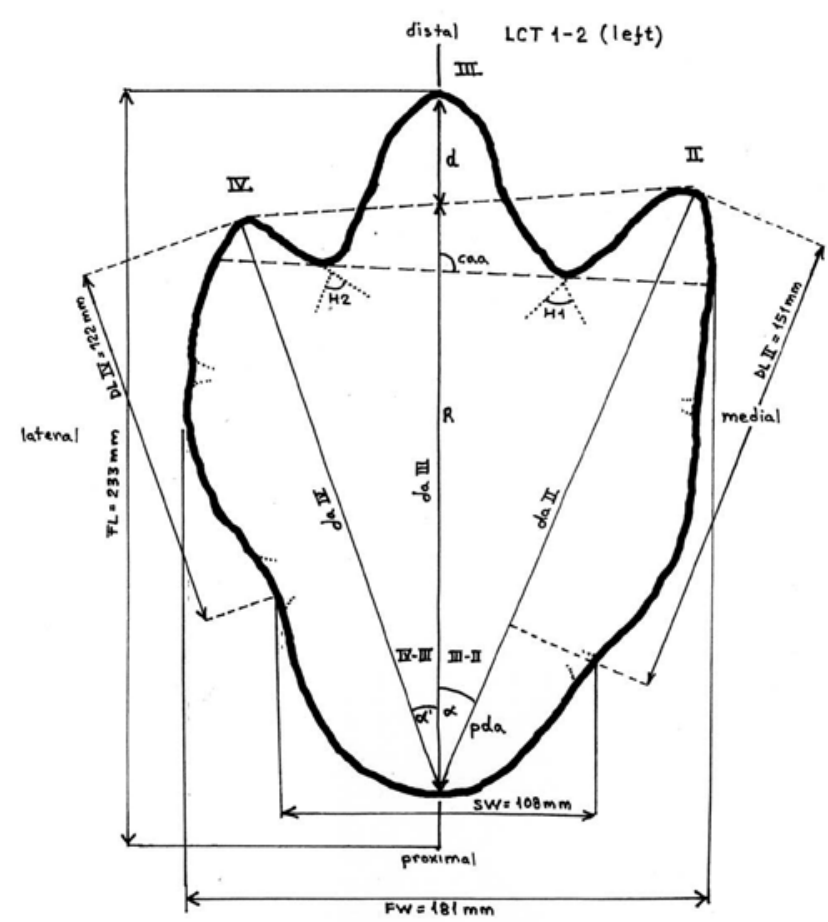

Fig.3. The morpho-dimensional parameters
A track segment with two consecutive footprints (LCT 1-1 right foot and LCT 1-2 left foot) was available for study. The best preserved one, as true impression is LCT 1-2, which provides the morphological data (Fig. 3; PI. I fig. 1; PI. II figs. 1-2). It is a medium sized slightly elongated $(F W / F L$ ratio $=$ 0.77) mesaxonic tridactyl footprint, preserving the digits (II-IV) and the sole (plantigrad condition). The print is $23.3 \mathrm{~cm}$ long (FL) and $18.1 \mathrm{~cm}$ in width (LW), enlarged at metapodial level. The third digit is quite short and wide, triangular and sharply pointed, the relative projection being indicated by the high value of $R / d$ ratio (5.2). The

lateral digits are unequal in length (apparent length: $\mathrm{DL} I V=12.2 \mathrm{~cm}$; $\mathrm{DL} \|=15.1$ $\mathrm{cm}$ ), the second digit is more robust, but the interdigital divartication angles have close values $\left(\mathrm{III}-\mathrm{III}=24^{\circ} ; \mathrm{III}-\mathrm{IV}=20^{\circ}\right.$; partial divartication angle $\left.=44^{\circ}\right)$. The hypex angle has also very close values $\left(\mathrm{H}_{1}=77^{\circ} ; \mathrm{H}_{2}=79^{\circ}\right)$ an almost symmetric condition, but the hypex widths suggest the pseudo-impression of the interdigital webs. The sole is narrow $(\mathrm{SW}=10.8 \mathrm{~cm})$ and has a round contour. The maximal thickness of relief (third digit metapodial/phalangeal junction) is $2.4 \mathrm{~cm}$.

Footprint data: thickness of relief $=2.4 \mathrm{~cm} ; \mathrm{FL}=23.3 \mathrm{~cm} ; \mathrm{FW}=18.1$ $\mathrm{cm}$; FW/FL ratio $=0.77 ; \mathrm{SW}$ (sole breath) $=10.7 \mathrm{~cm}$; DL (digit length) $\|=15.1 \mathrm{~cm}$, $\mathrm{III}=16.8 \mathrm{~cm}, \mathrm{IV}=12.2 \mathrm{~cm}$. R $/ \mathrm{d}$ ratio $=5.2$; $\mathrm{cca}$ (cross axis angle $)=93^{\circ} ; \mathrm{pda}$ 96 
(partial divartication angle $=44^{\circ}$; interdigital divartication angles II-III $=24^{\circ}$; III-IV $=$ $20^{\circ}$; dal (digit axis length) $\mathrm{II}=22 \mathrm{~cm}$, III $=23.3 \mathrm{~cm}$, IV $=20.2 \mathrm{~cm}$; hypex angles $\mathrm{H}_{1}=$ $77^{\circ}, \mathrm{H}_{2}=79^{\circ}$.

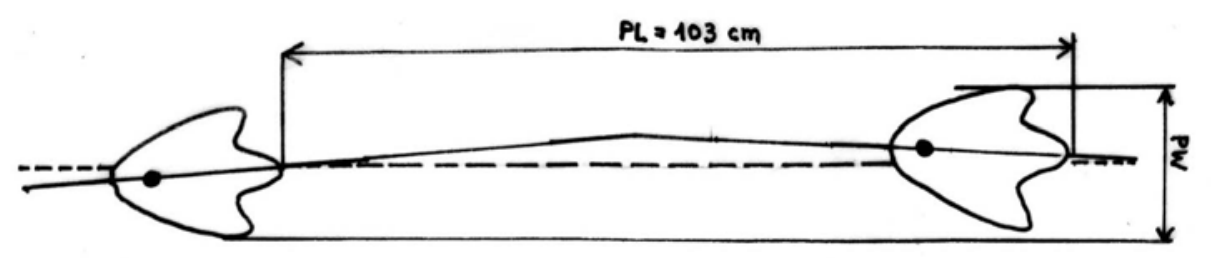

Fig.4 The LCT track (PL=pace length; PW pace breadth

The length of pace (PL) is $103 \mathrm{~cm}$ (Fig. 4; PI. I fig. 2), was measured between the proximal termination of the third digits. The length of stride (SL) represents almost double of PL (approximately $200 \mathrm{~cm}$ ), because the low pace angulation, and the minimal foot divartication from midline. On the preserved footprint pair, also can be observed a slightly inward (negative) rotation ( $5^{\circ}$ from the long axis).

Track data - calculated parameters: pace length $(\mathrm{PL})=103 \mathrm{~cm}$; low pace angulation; stride $(\mathrm{SL})=200 \mathrm{~cm}$; slightly inward (negative) rotation $-5^{\circ}$ from the long axis (divartication); hip height $(\mathrm{h})=107 \mathrm{~cm}$ (according to the formula: $\mathrm{h}=\mathrm{FL}$ $x 4.6$ used for small ornithopodes); gait $(\mathrm{g})=$ for gait indicative we use the formula $S L / h=1.87$ (accelerate) walking gait - sustained also by the plantigrad condition; speed $(\mathrm{V})=0.25 \times 0.935(\mathrm{~g} \times 0,5) \times 200(\mathrm{SL})^{1.67} \times 107(\mathrm{~h})^{-1.17}=6.87$ $\mathrm{km} / \mathrm{h}$.

\section{DISCUSSION AND PALEOECOLOGY}

The systematics and nomenclature of fossil tertrapod footprints is still a subject of dispute (Sarjeant, 1990), because instead of true fossils we have to deal with biogene or bioerozional structures, which not necesarely indicate the nature of trackmarker. However in the case of certain tetrapods, quite well preserved whole-footprints allowed to deduce the foot morphology and in the case of dinosaurs the trackmarker as well, at least to family or even generic level (Haubold, 1984; Sarjeant, 1990). In our case, a classification based on systematic affinity can be utilized, but the morphologic criteria and identification of trackmarking activity remains the most important.

Comparing our material with other Upper Cretaceous dinosaur footprints, from morphological and dimensional standing point, a great resemblance with the Ornithopod footprints (Ornithopedoidei) can be noticed. From the Maastrichtian continental deposits of Transylvania and Hat eg Basin, untill now, only two groups of Ornithopod dinosaurs are identified. The primitive hadrosaurs are represented by Telmathosaurus transylvanicus, but the lguanodonts "Rhabdodon" priscus and "Rhabdodon" robustus is also well known. The hadrosaur footprints (Hadrosaurichnus ALONSO group) differ from the LCT prints in a higher R/d and 
FW/FL ratios, much wider pes and toes as well as a blunted digit termination. Compared to the Hadrosaurs, the Iguanodont footprints (Iguanodontichnus CASAMIQUELA \& FASOLA group) have a lower R/d and FW/FL ratios, elongated and relatively sharp digits as well smaller sole (however this parameters are variable, doe to the preservation and diagenetic history). According to the morphological features and dimensional data, the LCT track belongs to the Iguanodontichnus group tentatively associated to "Rhabdodon", a very common "trackmarker" in the Maastrichtian continental deposits of Alba lulia region.

PERSONAL FILE: According to the track morpho-dimensional data, the following parameters can be calculated: individual). hip height $(h)=107 \mathrm{~cm}$; estimation of body length $(B L)=3.6 \mathrm{~m}$ (mature bipedal progression and accelerated walking gait (plantigrad condition); slightly inward rotation (which indicate an almost duck-like walking pattern). estimated speed $(\mathrm{V})=6.9 \mathrm{~km} / \mathrm{h}$.

PALAEOECOLOGY. The Lower Red Beds (or LRB) Fm exhibit a variety of facies indicating habitats corresponding to river channels, flood plains and crevasse splays, lakes and marshes (Codrea et al., 2001 a, b, 2002). Within the broad spectrum of these environments, dinosaur (mostly the sauropod Magyarosaurus dacus and ornithopods: Telmathosaurus transylvanicus, "Rhabdodon" priscus, "Rhabdodon" robustus, but also nodosaurids and other reptiles) bones occur in a large variety of facies. However, the ornithopod related footprints were identified only on a riverbank environment.

In the dinoturbated sequence, the lithofacial association Sp, Sh, respectively Sp, St, according to Miall (1985), indicates lateral accretion architectural element (LA). The large ammount of incarbonised and/or silicifiated tree-trunks and stumps (some of them 6-8 $\mathrm{m}$ long, roots included) accumulated in certain levels indicate a forrested environment. In the $\mathrm{Gm}$ unit situated right under the dinoturbated LA unit, the stumps are preserved also in situ (vertical position), which could indicate a heavy flood. Subsequently, the coarse gravel was covered by finer sediments (low angle cross laminated sand). Besides the foot-morphology, a quite well preserved footprint, allowed to deduce also the preservational context. The thickness of the relief is in accordance with the phisical state of substrate (Sarjeant, 1988). In our case, a relatively shallow surface-print (sensu Thulborn, 1990), as well as the pseudo-impression of interdigital webs occured due to the pressure of the addiacent digits in moist substrate. Other preservational features e.g. sediment displacement rims, are missing. In other words, the trackmarker follows a rout on relatively wet sand, along the riverbank (inner accretional facies). The dinoturbated layer, in short time was covered by finer sandy deposits which preserved it.

The paleontological and taphonomical studies carried out at Oarda de Jos and Lancră $m$ sites, indicate two main bone-accumulation facies. The channel-leg deposits consisting mainly of coarse conglomerates, provide 
especially long bones and vertebras with a paraautochton status, originating from different biotops (mixed fauna). The fine-grained channel-fill and overbank deposits accumulate a variety of skeletal elements (including skull fragments), which indicate certain biotops and a less mixed fauna. The wet-marshy areas were inhabited mostly by sauropods, but in the riverbank biotops the ornithopod dinosaurs were probably the most common. The general palaeofloristic data recorded from the Maastrichtian continental deposits of Alba lulia - Sebes area (Staub, 1889; Antonescu, 1973; Givulescu et al., 1995; lamandei, 1999), indicate a warm and wet bisezonal palaeoclimat, characterised by avarage annual temperatures of $18-20^{\circ} \mathrm{C}$.

\section{CONCLUSIONS}

The main importance of this discovery lies in its stratigraphical significance. The dinosaur footprints preserved within the LRB Fm. from Sebes area, highlight the Uppermost Cretaceous (Maastrichtian) age of the dinosaurbearing continental deposits cropping out along the Sebes River (Codrea et al., 2001 a,b), previously considered Oligocene, or even Miocene. Now we can also establish more precisely the autochthon/paraautochon status of some vertebrate assemblages recorded in these deposits. Until new discoveries, the preservational status of the above described footprints as well as the lack of information regarding European Upper Cretaceous ornithopod tracks, did not allow a firm ichnotaxonomic allocation (see discussion), however the trackmarker is regarded to be the iguanodontian "Rhabdodon", a very common ornithopod dinosaur. New data regarding size, locomotion and speed of the Transylvanian"Rhabdodon" are now added.

\section{Acknowledgements}

Authors express many sincere thanks to the following persons: $\operatorname{Dr}$ M. A Whyte (University of Sheffield, UK) and Dr L. Kordos (Geological Institute of Hungary), for useful comments and bibliography; Assist. E. Săsăran, Drd P. Dica and the students: Burián Szabolcs, Kovács Alpár and Tomas Róbert (BabeşBolyai University of Cluj-Napoca, Dept. of Geology-Paleontology) for their help on the field research. This research was partly supported by the CNCSIS grant \# $1243 / 2002$.

\section{REFERENCES}

Antonescu, 1973, Asociat ii palinologice caracteristice unor format iuni cretacice din Munt ii Metaliferi. Dă ri de seamă ale ședinț elor Institutului de Geologie și Geofizică , LIV: 115-469, București. 
Codrea, V., Hosu, Al., Filipescu, S., Vremir, M., Dica, P., Să să ran, E., Tanț ă u, I. 2001 a, Aspecte ale sedimentat iei cretacic superioare din aria Alba-lulia - Sebeș (jud. Alba). Studii și cercetă ri, Geologie-Geografie, 6: 63-68, Bistriț a.

Codrea, V., Barbu, O., Fă rcaș, C., 2001 b: O propunere de rezervație geologică paleontologică în județul Alba. Simpozionul științific internațional „Universitaria Ropet”, 18-20 octombrie 2001, Vol.: Ecologie și protecț ia mediului (8): 135-138, Petroșani.

Codrea, V., Să să ran, E., Dica, P., 2002, Vurpă r(Vinț u de Jos, Alba district). In: The 7th European Workshop of Vertebrate Palaeontology, Abstract Volume and Excursionas Field Guide, 60-62, Sibiu.

Dalla, Vecchia, F., M., Tunis, G., Venturini, S., Tarlao, A., 2001, Dinosaur track sites in the upper Cenomanian (Late Cretaceous) of Istrian Peninsula (Croatia). Bolletino della Società Paleontologica Italiana, 40 (1): 25-53, Modena.

Gierlinski, G. 1996, Dinosaur ichnotaxa from the Lower Jurassic of Hungary. Geological Quarterly, 40/1, pp. 119-128, London.

Givulescu, R., Codrea, V., Vremir, M. 1995, A new contribution to knowledge of Romanian Fossil Flora. Acta Palaeobotanica, 35/2, pp. 233-236, Krakow.

Haubold, H., 1984, Saurierfahrten. Die Neue Brehm-Bücherei, A. Ziemens Verlag, 231 S, Wittemberg-Lutherstadt.

lamandei, E., lamandei, S. 1999, Studii palaeoxilologice in România. Societatea Paleontologica Română. Actualită ți în Paleontologie, 6, pp. 12-16, București

Koch, A., 1900, Systematische Übersicht der fossilen Wilbertierreste der Länder der Ungarischen Krone. Magyar Orv. És Term.-Visg. Vándorgy. Munkálatai, 30: 526-560, Budapest.

Kordos, L. 1983, Fontosabb szorvanyleletek a MAFI gerinces-gyujtemenyben. Magyar Allami Foldtani Intezet evi Jelentese az 1981 evrol. Pp. 503-511, Budapest.

Leonardi, G. 1987, Glossary and Manual of Tetrapod Footprint Palaeoichnology. Departemento National da Producao Mineral, 117 pp., Brasilia.

Leonardi, G. 1984, Le Imprenti Fossili di Dinosauri. Pp 165-186 Ed. Erizzo, Venezia.

Lopez-Martinez, N., Fernandez-Marron, T., Valle, F. M., 1999, The succession of vertebrates and plants across the Cretaceous-Tertiary boundary in the Tremp Formation, Ager Valley (South-Central Pyrenees, Spain). Geobios, 32/4, pp. 617-627.

Lockley, M. 1991, Tracking Dinosaurs. A New Lokk at an Ancient World. Cambridge University Press

Miall, A., D., 1985, Architectural-Element Analysis: A New Method of Facies Analysis Applied to Fluvial deposits. Earth Sciences Revue, 22: 261-308.

Popa, M., 1999, First fiind of Mesozoic Tetrapod tracks in Romania. Acta Palaeontologica Romaniae 2 (1999): 387-390, Cluj-Napoca.

Romano, M., Whyte, M. A. 1996, Fossils explained 16: Trace fossils 3 - Dinosaur Tracks. 
THE FIRST LATE CRETACEOUS (MAASTRICHTIAN) DINOSAUR FOOTPRINTS ...

Geology Today, 1996/75

Să ndulescu, A., 1984, Geotectonica României. Ed. Tehnică , 336 p., București

Sarjeant, W. A. S., 1988, Fossil vertebrate footprints. Geology Today 4/4, pp. 125-129

Sarjeant, W. A. S., 1990, A name for the trace of act: approches to the nomenclature and classification of fossil vertebrate footprints. In: Dinosaur Systematics: Perspective and Approches, Carpenter, K., Currie, J, Ph. Eds. Cambridge University Press. Pp. 299-307.

Staub, M. 1889, Sabal major Unger a Maros volgyebol. Földtani Közlony, 19, pp. 258-264, Budapest.

Thulborn, R. A. 1990, Dinosaur Tracks. 424 pp., Chapman \& Hall, Andover.

Yu, X. Q., Kobayashi, Y., Lu, J. C., 1999, The preliminary study of the Dinosaur Footprints from Huangshan, Anhui Province. Vertebrata Palasiatica 1999/10, pp. 285290.

\section{PLATES}

\section{Plate I}

Fig. 1 : The plaster cast of LCT 1-2 footprint

Fig. 2 : The LCT track in situ

\section{Plate II}

Fig. 1, 2 : The LCT 1-2 footprint (different light conditions) 
MATEI VREMIR, VLAD A. CODREA

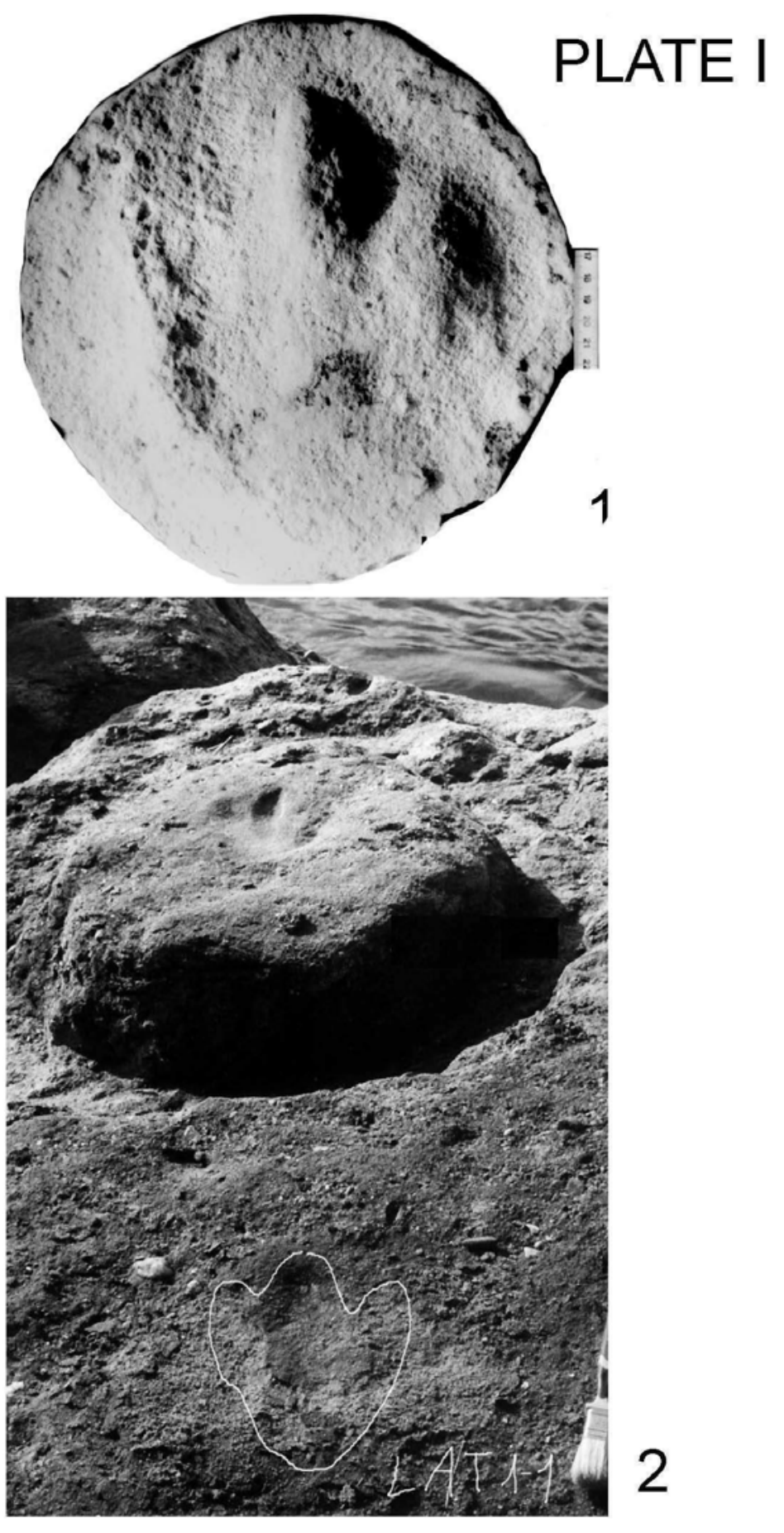


THE FIRST LATE CRETACEOUS (MAASTRICHTIAN) DINOSAUR FOOTPRINTS ...

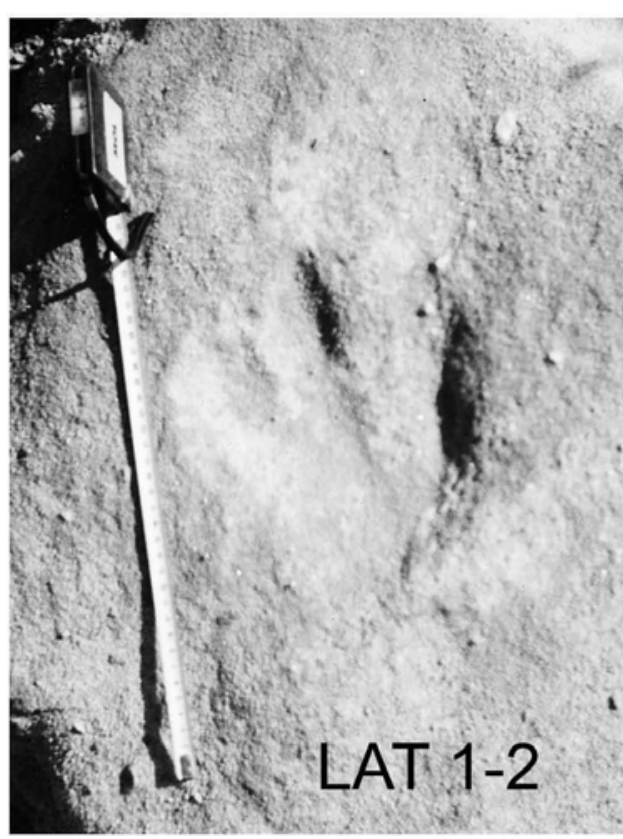

PLATE II

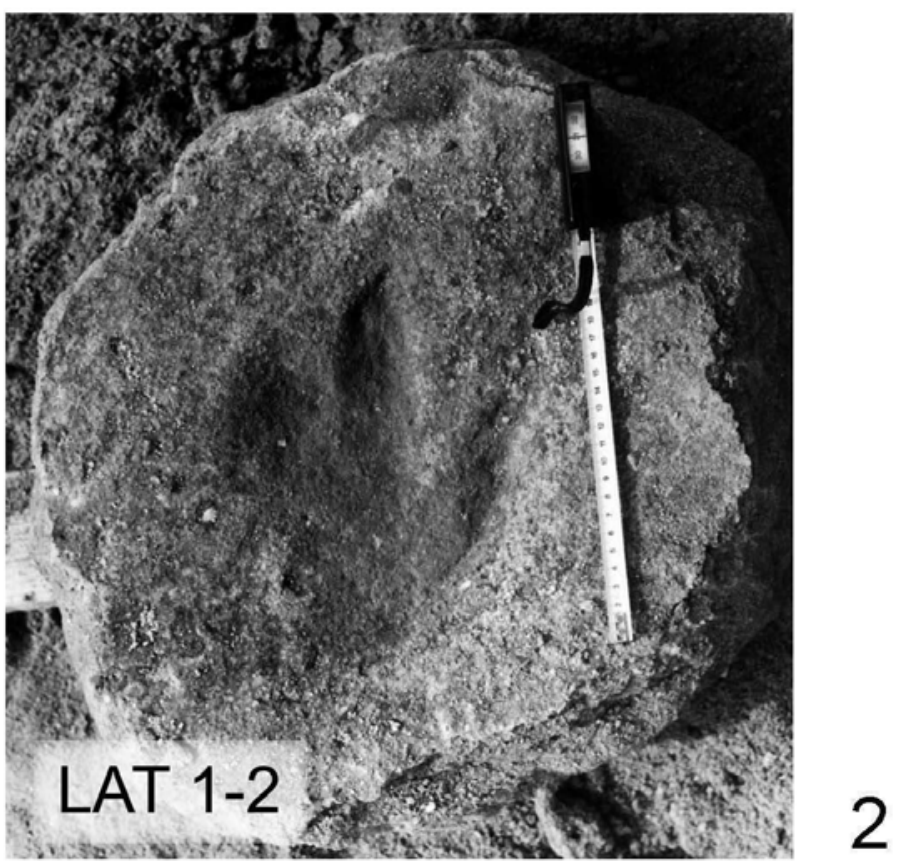

